\title{
Growth Rate and Histamine Production of Citrobacter freundii CK01 in Various Incubation Temperatures
}

\author{
Grace Margareta, Susana Endah Ratnawati, and Indun Dewi Puspita* \\ Department of Fisheries, Faculty of Agriculture, Universitas Gadjah Mada
}

\begin{abstract}
Improper handling and temperature fluctuations during postharvest of fish commonly allow the growth of histamine-forming bacteria (HFB) that may cause histamine poisoning. Citrobacter freundii CK01 is one of the HFB isolated from Skipjack landed on Sadeng, Yogyakarta. This study aimed to determine the temperature effect on the growth rate and histamine production by $C$. freundii CK01. Bacterial growth and histamine production was tested in tuna fish infusion broth (TFIB) at 5, 15, 30 and $40^{\circ} \mathrm{C}$. The bacterial growth was tested using Total Plate Count method, while histamine was determined using Thin Layer Chromatography and densitometry method. The primary model for bacterial growth was plotted with incubation time using DMFit referred to Baranyi \& Roberts model. The secondary model was converted from growth rate and modeled using Ratkowsky Square Root Model. The equation for growth rate of $C$. freundii CK01 was $\mu_{\max }=[0.0105(\mathrm{~T}+13.886)]^{2}$ (Root Mean Square Error $\left.<10 \%\right)$. Histamine production reached the highest concentration at $15^{\circ} \mathrm{C}$ in 96 hours up to $117,13 \mathrm{ppm}$. This study shows that temperature affected the growth rate and histamine production of $C$. freundii, indicating the importance of maintaining the low temperature stability during handling of skipjack.
\end{abstract}

\section{Introduction}

Indonesia has a great potential in fisheries, one of the main commodities is skipjack tuna. The increasing number of Skipjack's traffic in Indonesia from 2014-2017 grew by an average of $52.81 \%$ per year and reached 29.04 thousand tons indicating an increase in the consumption and trade distribution activities of skipjack in Indonesia[1]. Skipjack is the second largest commodity caught in Gunungkidul Yogyakarta and all year's catching season [2]. Skipjack contains high nutritional component: $71.75 \%$ water; $25.29 \%$ protein; $1.49 \%$ ash; $0.59 \%$ fat and $0.8 \%$ carbohydrate [3].

To maximize the potential value of Skipjack, products have to meet the quality standards. Histamine content in Skipjack is one of the quality parameter that needs to be considered not to exceed the limit in order to avoid poisoning. Histamine is a chemical that is toxic if found in large quantities in the body. The histamine poisoning symptoms are dizziness, stomach nausea, vomit, rapid heart rate, constant thirst, and itchiness [4]. At the end of 2017 until the

*Corresponding author: indun_dp@ugm.ac.id 
beginning of 2018, the United States Food and Drug Administration (US-FDA) sent a warning letter to 6 Indonesian fisheries companies related to HACCP in controlling food safety hazards from histamine formation [5]. In Indonesia, the extraordinary events of food poisoning (KLB) in 2000-2015 amounted to 61,119 cases and histamine poisoning contributed to $6.7 \%$ cases, whereas most cases were caused by pathogenic bacteria $(74.9 \%)$ [6]. Histamine from sardine consumption was also reported by the Lhokseumawe Health Office as a source of poisoning to 72 high school students [7].

The formation of histamine in fishery products are commonly due to the bad distribution chain, less attention of sanitation-hygiene and improper cold chains practice, resulting in temperature fluctuations. Improper handling temperatures can cause histamine-forming bacteria (HFB) growth and histidine decarboxylase enzymes to become active [8]. HFB produces the L-histidine decarboxylase enzyme, which converts free-histidine in fish to histamine [9].

Citrobacter freundii was categorized as the HFB with the low ability of histamine production, since among the 152 pure bacterial strains cultured in Triptone Soya Broth added with L-hystidine, $C$. freundii only produced less than $500 \mathrm{ppm}$ of histamine along with Hafnia [10]. C. freundii as one of the HFB in fish has not been widely studied to determine its potential as a histamine-causing agent. $C$. freundii CK01 originated from Skipjack in Sadeng Beach fish market was isolated in Niven's medium at $37^{\circ} \mathrm{C}$ [11]. The production of histamine by $C$. freundii CK01 in Tryptone Soya Broth $+0,1 \%$ L-histidine (TSBH) reached 1,600 ppm after $24 \mathrm{~h}$ of incubation at $37^{\circ} \mathrm{C}$ [11]. A similar study reported that $C$. freundii produced histamine up to $474 \mathrm{ppm}$ in chub mackerel sample after $48 \mathrm{~h}$ incubation at $30^{\circ} \mathrm{C}$ [12]. This study was conducted to characterize the growth of $C$. freundii $\mathrm{CK} 01$ at various temperatures and its ability in producing histamine. It is expected to provide information to minimize the risk of scromboid poisoning in Skipjack related to storage temperature controlling.

\section{Materials and methods}

\subsection{Medium preparation}

Tuna Fish Infusion Broth (TFIB) was prepared from fresh Katsuwonus sp. obtained from Sadeng Beach, Gunung Kidul, Yogyakarta. They were brought to the laboratory with styrofoam-box containing ice cubes, degutted, washed, then stored in the freezer overnight. The flesh were separated from the bone, washed, and homogenized with a blender in a water ration as twice as the weight of fish, then boiled at $100{ }^{\circ} \mathrm{C}$ for $1 \mathrm{~h}$. The mixture was cooled, filtered with Whatman No.1 filter paper, added with $1 \%$ glucose, put in a test tube of $10 \mathrm{~mL}$ each, and sterilized [13]. Tryptic Soy Agar (TSA) (Oxoid) and Tryptic Soy Broth (TSB) (Oxoid) were prepared following the manufacture's protocol.

\subsection{Inoculum preparation}

Citrobacter freundii CK0; a bacterial collection from The Laboratory of Fisheries Product Quality and Safety, Department of Fisheries, Faculty of Agriculture UGM; in glycerol stock was streaked on TSA medium and incubated for $24 \mathrm{~h}$ at $37^{\circ} \mathrm{C}$. The single colony was transfered into TSB and incubated for another $24 \mathrm{~h}$ at $37^{\circ} \mathrm{C}$. The TSB culture was used to prepare working culture on TSA slant. Inoculum was prepared by transfering cells using inoculating needle from working culture in to TSB, followed by incubation for $24 \mathrm{~h}$ at $37^{\circ} \mathrm{C}$.

\subsection{Citrobacter freundii CK01 growth in various temperature}


One loop of $C$. freundii CK01 inoculum prepared in TSB were cultured in TFIB and incubated at four temperature treatments: $5,15,30$ and $40^{\circ} \mathrm{C}$. Each treatment was done in two replicates. The temperature of 5 and $15^{\circ} \mathrm{C}$ were observed every $24 \mathrm{~h}$ for 5 days, while the temperature of 30 and $40^{\circ} \mathrm{C}$ every $3 \mathrm{~h}$ for $24 \mathrm{~h}$. During the observation, cell growth and histamine production were determined.

Cells growth were determined by calculating the cell number in the range of incubation time using the total plate count method. A $100 \mu \mathrm{L}$ C. freundii CK01 culture in TFIB from each treatment was transfered into $900 \mu \mathrm{L}$ Butterfield's phosphate buffer, homogenized, and made into serial dilutions. Each dilution was inoculated on TSA and incubated at $37 \pm 2{ }^{\circ} \mathrm{C}$ for $24 \pm 2 \mathrm{~h}$ before the calculation of cell number (log CFU/ml).

The histamine content produced in culture medium was determined semi-quantitatively using Thin Layer Chromatography (TLC) following previous method [14] with a modification in the spot analysis method. A $100 \mu \mathrm{L}$ bacterial culture in TFIB was harvested and centrifuged at 13,000 rpm for 10 minutes. Samples $(5 \mu \mathrm{L})$ were spotted on a $10 \times 20 \mathrm{~cm}$ TLC plate $60 \mathrm{~F}_{254}$ (Merck KGaA Germany). The plate was inserted into a chamber containing mobile phase solvent prepared from a mixture of ammonia and methanol with a volume ratio of 3:1. After the migration process completed, the plate was air dried and sprayed with a solution of ninhydrin (300 mg ninhydrin in $100 \mathrm{~mL}$-butanol added with $3 \mathrm{~mL}$ of glacial acetic acid) to develop spots. The histamine solutions (100 to 1,000 ppm) prepared by diluting Histamine powder (TCI, Germany) in $1 \mathrm{M} \mathrm{HCl}$ were used as standard. The same procedure was applied for the L-histidine (TCI, Germany) standard solutions (1,000 to 10,000 ppm). The standard solutions were also spotted on to the TLC plate and following the same steps with the samples. The TLC plate was scanned and spots were analyzed to determine their area values using ImageJ program. The area of standards were plotted with the known concentration of standards resulting to the linear regression equation that were used to convert the area of the samples into the histamine or histidine concentration (ppm).

\subsection{Data analysis}

The data of cell number in each incubation time were used to obtain growth curve at various temperatures with an Excel program. The primary model of bacterial growth was obtained using the DMFit software (http://www.combase.cc) based on Baranyi and Roberts model [24]. The square rooted of growth rate $\left(\mu_{\max }\right)$ was made and plotted with temperature to obtain bacterial growth model in the function of temperature using Ratkowsky Square Root Model (RSRM) [24].

$$
\mu_{\max }=\left[\mathrm{b}_{1}\left(\mathrm{~T}-\mathrm{T}_{\min }\right)\right]^{2}
$$

$\mu_{\max }=$ maximum specific growth rate $(\log \mathrm{CFU} / \mathrm{h})$

$\mathrm{T}=$ temperature $\left({ }^{\circ} \mathrm{C}\right)$

$\mathrm{b}_{1}=$ regression coefficient to be estimated

$\mathrm{T}_{\min }=$ extrapolation temperature, showing the minimum temperature for bacterial growth $\left({ }^{\circ} \mathrm{C}\right)$

The accuracy of Ratkowsky's model was assessed by calculating the value of Root Mean Square Error (RMSE) according to the equation expressed by Den Besten et al. [15].

$$
R M S E_{\text {model }}=\sqrt{\frac{\sum_{i=1}^{n}\left(\text { observed }_{i}-\text { fitted }_{i}\right)^{2}}{n-s}}
$$

observed $_{\mathrm{i}}=$ value of observation

fitted $_{i}=$ predictive value

$\mathrm{n}=$ amount of data

$\mathrm{s}=$ number of parameters of the model 


\section{Results and discussion}

\subsection{Citrobacter freundii CK01 growth in various temperature}

The growth of $C$. freundii CK01 in TFIB at 5, 15, 30 and $40^{\circ} \mathrm{C}$ are shown in Figure 1 . The results show that the number of cell increased significantly at temperature of 30,40 and $15^{\circ} \mathrm{C}$, whereas at $5^{\circ} \mathrm{C}$ the bacteria cell number tended to be lower than other temperatures. The highest increase in cell number of $C$. freundii CK01 was shown at $30^{\circ} \mathrm{C}$, from 4.25 to 8.16 $\log \mathrm{CFU} / \mathrm{mL}$ within $18 \mathrm{~h}$. A slight lower in cell number was observed at $40^{\circ} \mathrm{C}$, from 4.88 to $7.89 \log \mathrm{CFU} / \mathrm{mL}$ after $24 \mathrm{~h}$. Whereas at $15^{\circ} \mathrm{C}$, an increase in cell number was observed at the first $24 \mathrm{~h}$, from 4.23 to $7.19 \log \mathrm{CFU} / \mathrm{mL}$. The similar results were reported by Behling and Taylor [16]. The number of $C$. freundii at $30^{\circ} \mathrm{C}$ increased significantly, from 7.1 to $9 \mathrm{log}$ $\mathrm{CFU} / \mathrm{g}$ after $48 \mathrm{~h}$ incubation, while at $37^{\circ} \mathrm{C}$ increased from 7 to $8.6 \log \mathrm{CFU} / \mathrm{g}$. They also showed that the number of $C$. freundii incubated for $72 \mathrm{~h}$ at low temperatures $\left(-3\right.$ and $\left.0^{\circ} \mathrm{C}\right)$ increased in a small amount, from 7 to $7.5 \log \mathrm{CFU} / \mathrm{g}$. Meanwhile, at $15^{\circ} \mathrm{C}, \mathrm{C}$. freundii showed fairly increase in the first $24 \mathrm{~h}$, from 7.2 to $8.8 \log \mathrm{CFU} / \mathrm{g}$.

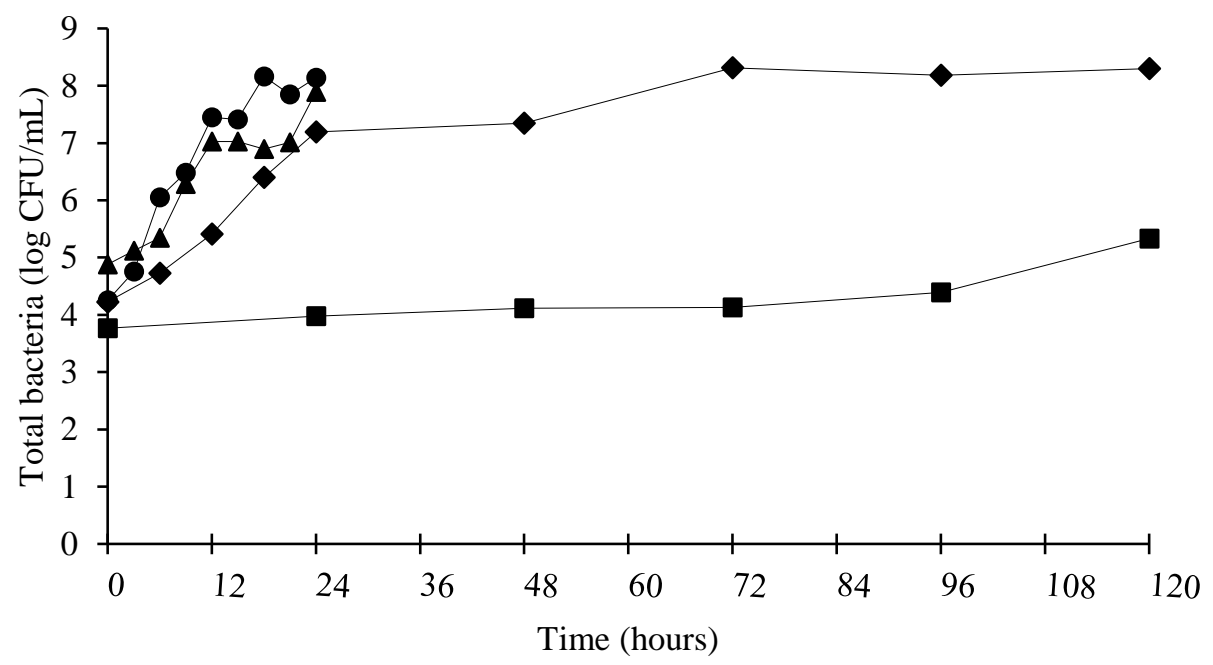

Fig. 1. C. freundii $\mathrm{CK} 01$ growth in TFIB incubated at $5^{\circ} \mathrm{C}(\boldsymbol{\bullet}) ; 15^{\circ} \mathrm{C}(\bullet) ; 30^{\circ} \mathrm{C}(\bullet)$ and $40^{\circ} \mathrm{C}(\boldsymbol{\Delta})$

The cell growth data of C. freundii CK01 were analyzed using DMFit to determine the bacterial growth rate $\left(\mu_{\max }\right)$. Overall, the $\mu_{\max }$ increased with the temperatures. The smallest value of $\mu_{\max }$ was observed at $5^{\circ} \mathrm{C}$, followed by $15^{\circ} \mathrm{C}, 30^{\circ} \mathrm{C}$, and the highest $\mu_{\max }$ was at $40^{\circ} \mathrm{C}$ (Table 1). 
Table 1. C. freundii CK01 growth rate in DMFit analysis

\begin{tabular}{|c|c|c|c|}
\hline $\begin{array}{c}\text { Temperature } \\
\left({ }^{\circ} \mathrm{C}\right)\end{array}$ & $\begin{array}{c}\mu_{\max } \\
(\log \mathrm{CFU} / \mathrm{h})\end{array}$ & $\begin{array}{c}\mathrm{N}_{\max } \\
(\log \mathrm{CFU} / \mathrm{mL})\end{array}$ & $\begin{array}{c}\text { Incubation } \\
(\mathrm{h})\end{array}$ \\
\hline 5 & $0.044 \pm 0.06$ & $5.36 \pm 1.24$ & 120 \\
\hline 15 & $0.096 \pm 0.04$ & $8.30 \pm 0.07$ & 120 \\
\hline 30 & $0.290 \pm 0.17$ & $8.25 \pm 0.14$ & 24 \\
\hline 40 & $0.295 \pm 0.23$ & $7.89 \pm 0.45$ & 24 \\
\hline
\end{tabular}

C. freundii optimally grows at $37^{\circ} \mathrm{C}$ [17]. Above the optimal temperature, denaturation of protein occurs resulting to the cellular disfunction, whereas under optimal temperature, bacteria lost their membrane function resulting to the disruption of bacterial metabolism [17]. The relationship between temperature and bacterial $\mu_{\max }$ was determined and modeled in the temperature functions using Ratkowsky Square Root Model (RSRM) [24]. The mathematical equation describing the relationship of temperature and bacterial growth rate square root of C. freundii CK01 was $\mathrm{y}=0.0105 \mathrm{x}+0.1458$ with $\mathrm{R}^{2}=0.9235$ (Figure 2). A slight decrease in growth rate square root was observed at $40^{\circ} \mathrm{C}$. It indicates that $40^{\circ} \mathrm{C}$ was slightly above the optimum temperature for $M$. morganii growth. A similar finding was found in other study which showed that the square root value of $M$. morganii growth rate increased with increasing temperatures up to $40^{\circ} \mathrm{C}$, but at a temperature of $45^{\circ} \mathrm{C}$ the growth rate square root decreased [18].

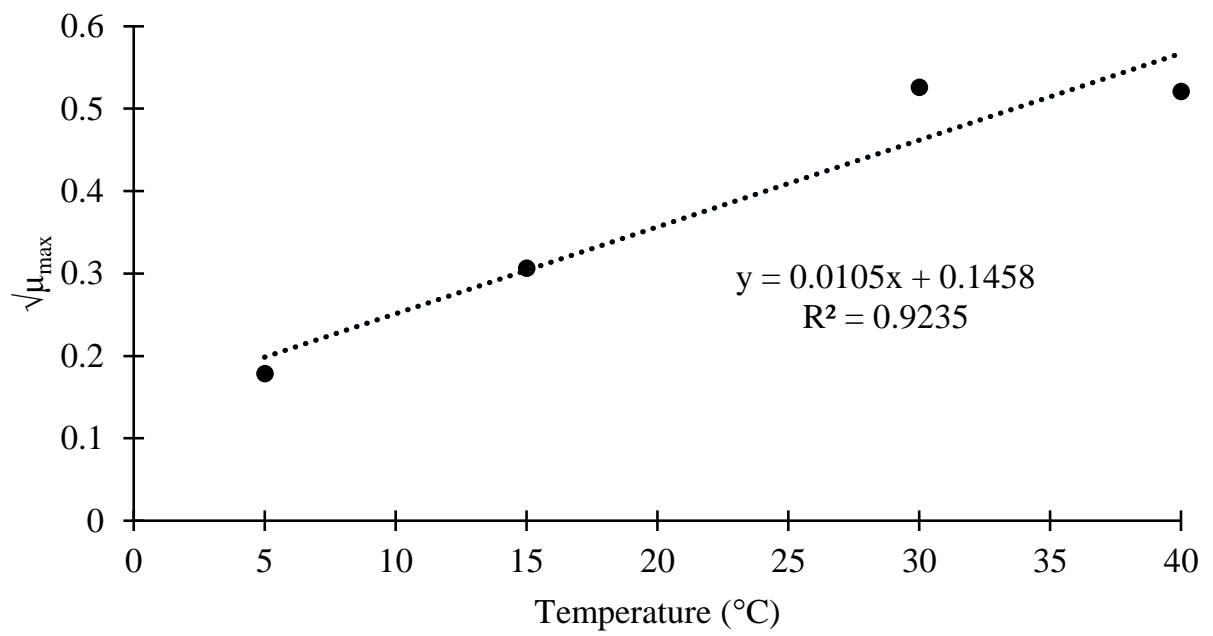

Fig. 2. The relationship of $C$. freundii CK01 growth rate square root and temperature based on Ratkowsky Square Root Model (RSRM)

The growth prediction model of $C$. freundii CK01 in the function of temperature was $\mu_{\max }$ $=[0.0105(\mathrm{~T}+13.886)]^{2} . \mathrm{T}_{\min }$ is the minimum temperature when the growth rate is equal to 0 . The $\mathrm{T}_{\min }$ value of $C$. freundii $\mathrm{CK} 01$ obtained by this model was lower than other HFB isolated from the same fish, Klebsiella sp. CK02, which produced $\mathrm{T}_{\min }$ of $-8.89^{\circ} \mathrm{C}$ [11]. The lower the $\mathrm{T}_{\min }$ value, the lower the temperature needed to deactivate bacterial growth. The ability of $C$. freundii grown at $0^{\circ} \mathrm{C}$ was reported by the increasing of the cell number from 7 to $7.5 \log \mathrm{CFU} / \mathrm{g}$ after $158 \mathrm{~h}$ incubation [16]. It indicates that $C$. freundii CK01 had a considerable growth resistance in low temperature conditions. This prediction model is useful 
to determine shelf life, optimize storage conditions, and for further study of histamine exposure assessments [18].

Table 2. Predicted growth model of $C$. freundii CK01 in temperature function

\begin{tabular}{|l|c|c|c|c|}
\hline \multicolumn{1}{|c|}{ Bacteria } & T $_{\min }$ & b & RMSE & Prediction Model \\
\hline C. freundii CK01 & -13.89 & 0.0105 & 0.04 & $\mu_{\max }=[0.0105(\mathrm{~T}+13.886)]^{2}$ \\
\hline Klebsiella sp. CK02 $^{\mathrm{a}}$ & -8.89 & 0.0119 & 0.05 & $\mu_{\max }=[0.0119(\mathrm{~T}+8.889)]^{2}$ \\
\hline${\text { M. } \text { morganii ATCC } 25830^{\mathrm{a}}}^{\mathrm{a}}$ & -2.48 & 0.0184 & 0.05 & $\mu_{\max }=[0.0184(\mathrm{~T}+2.483)]^{2}$ \\
\hline
\end{tabular}

${ }^{a}$ Dityanawarman (2018)

\subsection{Histidine and histamine production by C. freundii CK01 in TFIB}

The histidine standard was detected on the TLC plat as the pink color spot with the Rf value of 0.56 , whereas histamine standard was dark red with the Rf value of 0.26 (Figure 3). The histamine standards below $100 \mathrm{ppm}$ and above $1,000 \mathrm{ppm}$ was failed to be read as the ImageJ program was not able to distinguish the area values of the spots. The linear regression equation of $\mathrm{y}=0.0008 \mathrm{x}+0.0898\left(\mathrm{R}^{2}=0.9021\right)$ was used to estimate the histamine concentration, meanwhile the equation of $y=0.0001 x-0.1645\left(R^{2}=0.9363\right)$ was used to estimate the histidine concentration in bacterial culture medium, whereas $\mathrm{y}$ was the area value.
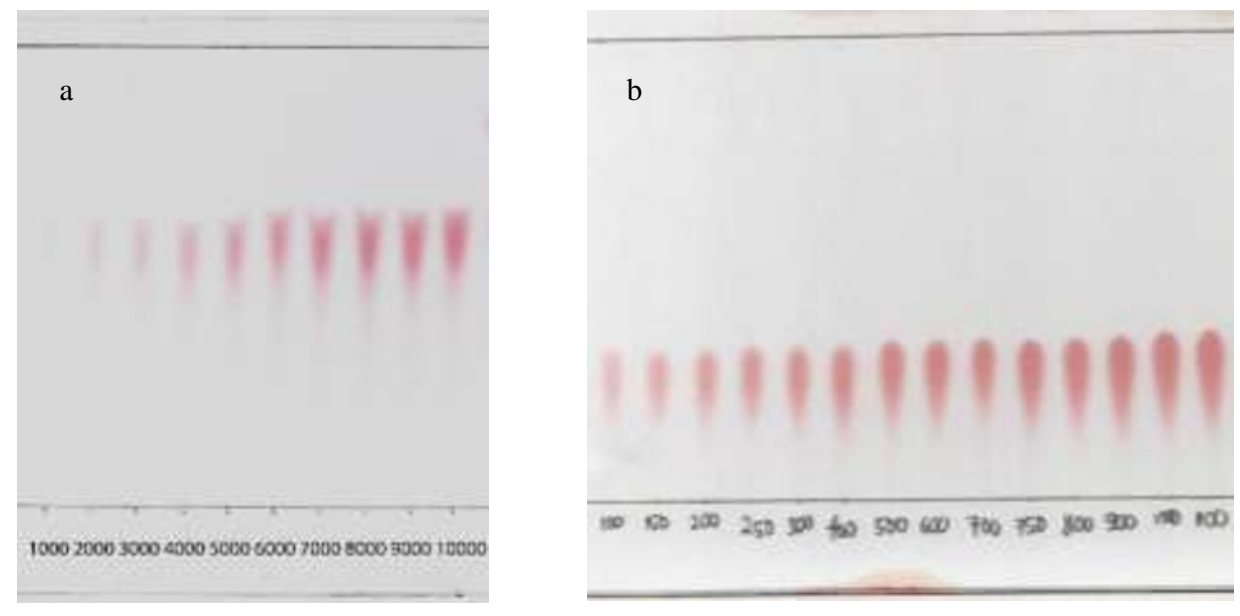

Fig. 3. Visualization of histidine (a) and histamine standards (b) stained on TLC plate

Histidine concentration in the medium and histamine formation by C. freundii CK01 are shown in Figure 4. At 5 and $40^{\circ} \mathrm{C}$, the histamine was not detected and histidine concentration did not decrease, indicating that histamine was not produced during the experiment or produced in a low level below the detectable range. $C$. freundii was reported to have no significant histamine production after incubation at $7^{\circ} \mathrm{C}$ for $158 \mathrm{~h}$ [16]. C. freundii CK01 at 5 and $40^{\circ} \mathrm{C}$ showed a lower growth rate and the histamine production was not detected (below 100 ppm). 

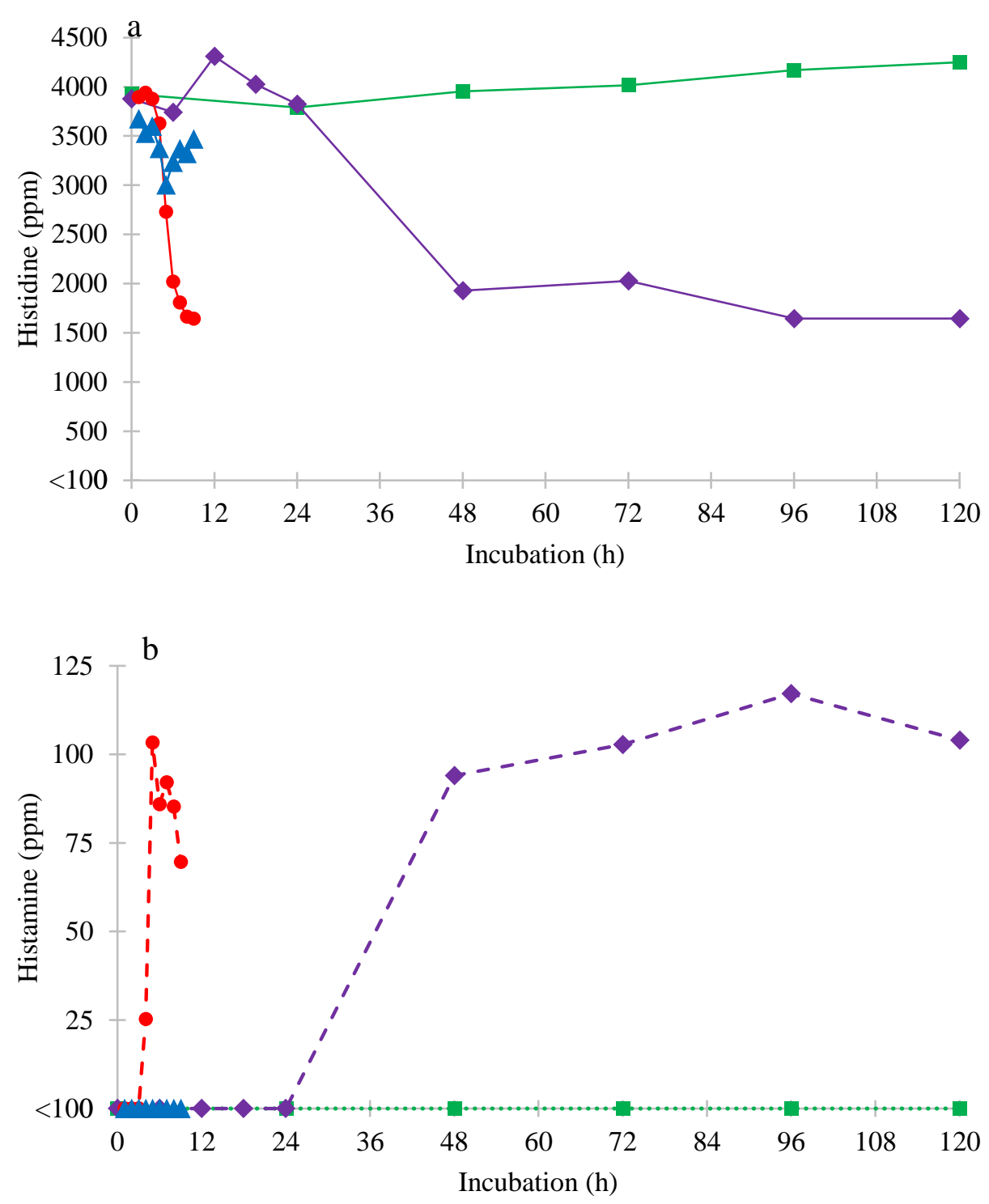

Fig. 4. Histidine levels (a) in TFIB and formation of histamine (b) by C. freundii CK01 at various temperature treatments. Levels of hitidine $(--)$ and histamine $(---)$ in $5^{\circ} \mathrm{C}(\varpi) ; 15^{\circ} \mathrm{C}(\diamond)$; $30^{\circ} \mathrm{C}(\bullet)$ and $40^{\circ} \mathrm{C}(\boldsymbol{\Delta})$. The dashed line $(\cdots \cdots)$ shows histidine / histamine levels below 100 $\mathrm{ppm}$

The formation of high histamine concentration were detected at 15 and $30^{\circ} \mathrm{C}$. The highest histamine formation was shown at a temperature of $15^{\circ} \mathrm{C}$ with an initial histamine of $94 \mathrm{ppm}$ at $48 \mathrm{~h}$ to $117.13 \mathrm{ppm}$ at $96 \mathrm{~h}$. At $30^{\circ} \mathrm{C}$ the histamine formation reached $103.38 \mathrm{ppm}$ within just $12 \mathrm{~h}$. The optimal temperature of histamine production by $C$. freundii was reported at $37^{\circ} \mathrm{C}$, reaching $220 \mathrm{ppm}$ after $72 \mathrm{~h}$ incubation in TSBH [16]. High histamine formation was also reported for $C$. freundii which produced $474 \pm 9 \mathrm{mg} / \mathrm{L}$ (equivalent to ppm) histamine after $48 \mathrm{~h}$ incubation at $30^{\circ} \mathrm{C}$ in TSBH [12]. The results in this experiment tend to show less histamine levels produced by $C$. freundii compared to the other two previous studies [16,12]. 
This was probably because of the different medium that were used. The production rate of histamine is affected by the free-histidine availability in the medium [21]. The higher the substrate concentration, the higher the product is produced, the histidine concentration as the substrate will affect the amount of histamine formed [19]. This explained the abundance of histamine found in Scromboidae fishes is due to their high content of free histidine in the muscle tissues [12].

The optimal temperature for histamine formation by $C$. freundii CK01 was different from the temperature of the highest growth rate. The highest histamine formation was produced at $15^{\circ} \mathrm{C}$ in 96 hours of incubation while the highest growth rate of bacteria was achieved at $40^{\circ} \mathrm{C}$ in 24 hours incubation time. This result indicates that handling of skipjack at $15^{\circ} \mathrm{C}$ for a long period was potential for histamine accumulation. Moreover, the data shows that a high number of HFB in the sample was not directly related to a high concentration of histamine in the sample. Presumably the optimal temperature for bacterial metabolism that affected growth is different from the optimal temperature of the hitidine decarboxylation enzyme works. Similar trend was reported in Proteus morganii which showed a temperature difference for an optimal growth $\left(37^{\circ} \mathrm{C}\right)$ with the highest histamine production $\left(24\right.$ and $\left.30^{\circ} \mathrm{C}\right)$ [20]. Another reported was in Photobacterium phosphoreum YS4-7 which showed the highest growth at $27^{\circ} \mathrm{C}$ while the highest histamine concentration was produced at $20^{\circ} \mathrm{C} \mathrm{[23].}$

\section{Conclusion}

This study shows the effect of temperature on the growth rate and histamine production ability of $C$. freundii CK01. Temperature fluctuations that occur during the process of skipjack tuna handling allow growth of $C$. freundii CK01 with varying growth rates that could be calculated by the equation $\mu_{\max }=[0.0105(T+13.886)]^{2}$. The most important finding in this study was $C$. freundii CK01 showed growth, although in a very low rate, at low temperature $5^{\circ} \mathrm{C}$. It indicates that the cell number might increase to a significant level when the low temperature handling proceeds for long period. Eventhough $C$. freundii CK01 did not produce a significant level of histamine at $5^{\circ} \mathrm{C}$, the high initial cell number in the fish due to its ability to grow at low temperature during handling might resulted to the high rate of histamine formation when there is a temperature abuse. The recommended fish storage temperature is determined through the $\mathrm{T}_{\text {min }}$ value as the minimum temperature for bacterial growth, from this study it is recommended that safe storage temperature for Skipjack is around $-13^{\circ} \mathrm{C}$ to prevent histamine production. This study illustrates the importance of striving for low temperature stability and a short time in handling fresh skipjack.

\section{Acknowledgement}

This study was funded by the research grant from the Faculty of Agriculture UGM in fiscal year of 2018/2019.

\section{References}

1. KKP (Kementerian Kelautan dan Perikanan), https://kkp.go.id/kkp/bkipm/artikel/ 5836-peta-lalulintas-ikan-cakalang-nasional-2018-volume-1 (2018)

2. R. Anggraeni, S. Anhar, W. S Suradi, Diponegoro J. Maq. 4, 3 (2015)

3. Y. Ekawati, IPB Thesis (2014)

4. N. Hattu, I. Telussa, S Paiss, Ind. J. Chemis. 2 (2014) 
5. K.M. Mackin, https://www.foodsafetynews.com/2018/02/fda-sends-warning-lettersto-six-seafood-importers-in-indoensia/ (2019)

6. R.R. Arisanti, I. Citra, A.W. Siswanto, 34, 3 (2017)

7. Bakri, http://aceh.tribunnews.com/2015/08/31/keracunan-siswa-arun-akibat-histamin (2015)

8. H. Takahashi, M. Ogai, S. Miya, T. Kuda, B. Kimura, F. Cont. 52 (2015)

9. D.H. Yoshinaga, H.A. Frank, App. Env. Mic. 44, 2 (1982)

10. B.K. Butler, G.E. Bolton, L.A. Jaykus, P.D. McClellan-Green, D.P. Green, Intr. J. Food Mic. 139 (2010)

11. A. Dityawarman, UGM Thesis (2018)

12. J.W. Hu, M.J. Cao, S.C. Guo, L.J. Zhang, W.J. Su, G.M Liu, J. Food Prot. 78, 2 (2015)

13. Y. Omura, R.J. Price, H.S. Olcott, J. Food. Sci. 43 (1978)

14. Z. Bajc, K.S. Gačnik, J. Pla. Chr. 22, 1 (2009)

15. H.M.W. Den Besten, M. Mataragas, R. Moezelaar, T. Abee, M.H. Zwietering, App. Env. Mic. 72 (2006)

16. A.R. Behling, S.L. Taylor, J. Food Sci. 47 (1982)

17. M.L. Droffner, F. William, J. Brinton, E. Eric, Biomass. Bioan. 8, 3 (1995)

18. J. Emborg, P. Ahrens, P. Dalgaard, Danish Institute for Fisheries Research Disertation (2007)

19. A.R. Permanasari, F. Yulistiani, R.W. Purnama1, T. Widjaja, S. Gunawan, IOP Conf. Ser.: Earth Environ. Sci. 160 (2018)

20. R.R. Eitenmiller, J.W. Wallis, J.H Orr, R.D. Phillips, J. Food. Protc. 44, 11 (1981)

21. D.G. Allen Jr, NCSU Thesis (2004)

22. J. Baranyi, T.A. Roberts, Int. J. Micro. 26 (1995)

23. M. Kanki, T. Yoda, T. Tsukamoto, T. Shibata, App. Env. Mic. 68, 7 (2002) 